\title{
Influences of Bath Chemistry and Plating Variables on Characteristics of Electroless Ni-P Films on Si Wafers from Alkaline Citrate Solutions
}

\author{
Naiming Miao, , ${ }^{1,2}$ Jinjin Jiang, ${ }^{2}$ and Wangping $\mathrm{Wu} \mathbb{D}^{2,3}$ \\ ${ }^{1}$ School of Mechanical Engineering, Jiangsu University, Zhenjiang 212013, China \\ ${ }^{2}$ Electrochemistry and Corrosion Laboratory, School of Mechanical Engineering, Changzhou University, Changzhou 213164, China \\ ${ }^{3}$ Changzhou High Technology Research Key Laboratory of Mould Advanced Manufacturing, School of Mechanical Engineering, \\ Changzhou University, Changzhou 213164, China
}

Correspondence should be addressed to Wangping Wu; wwp3.14@163.com

Received 5 April 2018; Accepted 10 May 2018; Published 27 September 2018

Academic Editor: Xuping Sun

Copyright (c) 2018 Naiming Miao et al. This is an open access article distributed under the Creative Commons Attribution License, which permits unrestricted use, distribution, and reproduction in any medium, provided the original work is properly cited.

\begin{abstract}
Electroless nickel-phosphorus (Ni-P) films were produced on the surface of p-type monocrystalline silicon in the alkaline citrate solutions. The influences of bath chemistry and plating variables on the chemical composition, deposition rate, morphology, and thermal stability of electroless Ni-P films on silicon wafers were studied. The as-deposited Ni-P films were almost all medium- and high-P deposits. The concentrations of $\mathrm{Ni}^{2+}$ and citric ions influenced the deposition rate of the films but did not affect $\mathrm{P}$ content in the deposits. With increasing $\mathrm{H}_{2} \mathrm{PO}_{2}^{-}$content, the $\mathrm{P}$ content and deposition rate were steadily increased. The $\mathrm{pH}$ and plating temperature had a significant effect on the chemical composition and the deposition rate of the films. The thermal stability of the medium-P film was better than that of the high-P deposit. At the same time, the proposed mechanism of Ni-P films on monocrystalline silicon substrates in the alkaline bath solution was discussed and addressed.
\end{abstract}

\section{Introduction}

Electroless process of metal and alloy films makes nanometer-scale structures on silicon $(\mathrm{Si})$ wafers due to its simplicity and ability to fill in fine patterns. The mass production of metallic structures on Si wafer is one of key techniques in micro- and nanoscale device applications $[1,2]$, such as single-electron transistors [3,4], patterned recording media [5], highly integrated sensors [6,7], ultralarge-scale integration metallization [8], and ohmic contacts [9].

Electroless $\mathrm{M}$-phosphorus ( $\mathrm{M}=\mathrm{Ni}, \mathrm{Co})$ deposition is the most important catalytic deposition process, due to its simplicity in operation, low equipment cost, and excellent properties in wear and corrosion. More recent work about M-P nanomaterial could be prepared by electrodeposition $[10,11]$ and phosphiding the hydrothermally grown precursor [12-15], which could be used as electrocatalyst for alkaline oxygen evolution reaction. In comparison with the above two processes, the electroless is an easy, cost-effective, and save-energy method. Electroless $\mathrm{Ni}-\mathrm{P}$ deposition reaction can occur in an alkaline or acid environment. To study the autocatalytic deposition of $\mathrm{Ni}$ accompanied by $\mathrm{P}$ incorporation in the film, it is necessary to know the effect of the operating parameters and bath chemistry on the deposition rate and the quality of the deposits, such as the substrate nature [16], $\mathrm{pH}[17,18]$, plating temperature [19], stirring [20], light [21], stabilizers [22], complexing agent [23], and additives [24]. In order to perform deposition of electroless $\mathrm{Ni}-\mathrm{P}$, the substrate surface needs to be preactivated and presensitized. Chen et al. [16] found that the crystallization of amorphous Si thin films was induced by electroless plating Ni. The crystallinity of amorphous Si increased with electroless $\mathrm{Ni}$ plating time but dropped when the time reached $10 \mathrm{~min}$. Homma [25] investigated that electroless Ni-P films were deposited onto dielectric substrates and found that the films consisted of fine component crystals with uniform 
and spherical grains at the initial deposition stage. Xie and Zhang [26] reported the effects of bath chemistry and plating conditions on the structure and amorphous-forming region for electroless $\mathrm{Ni}-\mathrm{P}$ on copper substrates in the alkaline bath solution at a bath temperature of $90^{\circ} \mathrm{C}$ and discovered that the deposition rates increased and approached a maximum value and then decreased with the increase in the concentration of $\mathrm{Ni}^{2+}$, sodium hypophosphite, and $\mathrm{pH}$ value, respectively. However, the deposition rates decreased with the increase in sodium citrate. Rahman and Jayaganthan [18] studied the effect of $\mathrm{pH}$ on electroless $\mathrm{Ni}-\mathrm{P}$ films on the surface of mild steel and concluded that the Ni content increased with increasing $\mathrm{pH}$. Moniruzzaman and Roy [17] reported that electroless $\mathrm{Ni}-\mathrm{P}$ coating was produced on carbon steel and polypropylene substrates and pointed out that the coating of good appearances was obtained in the $\mathrm{pH}$ ranges between 5.5 and 12.5 on carbon steel and between 8.5 and 12 on the polypropylene. Singh et al. [21] investigated the effect of lights on the electroless Ni-P films and found that electroless deposition under the dark was the most suitable for $\mathrm{Ni}-\mathrm{Cu}$ metallization process. Bulasara et al. [20] researched that the stirring had a profound effect on sodium hypophosphite-based electroless $\mathrm{Ni}$ baths, which were characterized with lower conversions and higher plating efficiencies without stirring condition. Jappes et al. [22] studied that the effects of stabilizers and bath temperature on efficiency and crystallinity of the electroless $\mathrm{Ni}-\mathrm{P}$ on the mild steel. Ashtiani et al. [23] published the effect of different complexing agents, such as sodium citrate, sodium acetate, and lactic acid, on the $\mathrm{P}$ content, morphology, structure, and hardness of electroless $\mathrm{Ni}-\mathrm{P}$ on Ck45 steel and found that $\mathrm{Ni}-\mathrm{P}$ coating obtained using sodium citrate with the spherical nodular structure and smooth surface showed high microhardness and anticorrosion resistance. Liu et al. [19] studied the effects of $\mathrm{pH}$ and bath temperature on electroless $\mathrm{Ni}-\mathrm{P}$ on $\mathrm{Si}$ in an acid plating bat and found that the deposition rate increased as both $\mathrm{pH}$ and temperature increased. Zhang et al. [24] studied that the improved quality of Ni film on Si (100) substrates in aqueous alkaline solution can be attributed to the fine and dense nickel particles formed in the initial stage by virtue of the fluorine ion, concentrated $\mathrm{Ni}^{2+}$ ion, and elevated temperature. Recently, $\mathrm{Wu}$ and Jiang [27] published that electroless $\mathrm{Ni}-\mathrm{P}$ film was deposited on the surface of polycrystalline $\mathrm{Si}$ in the alkaline bath solutions at the temperature of $60-80^{\circ} \mathrm{C}$ and $\mathrm{pH}$ of 10.0 and found that the films were composed of the amorphous phase, regardless of bath temperature. However, few publications reported the influences of bath chemistry and plating variables on electroless $\mathrm{Ni}-\mathrm{P}$ films on $\mathrm{Si}$ wafers from alkaline citrate solutions.

In the present work, the $\mathrm{Ni}-\mathrm{P}$ film was electrolessly produced in an alkaline bath solution on the surface of p-type monocrystalline $\mathrm{Si}$ substrates from alkaline citrate solutions. The influences of bath chemistry and plating parameters on the chemical composition, deposition rate, and morphology of $\mathrm{Ni}-\mathrm{P}$ film were investigated in detail; at the same time, the thermal stability and proposed mechanism of the deposit were studied.
TABLE 1: Bath composition and operation conditions for electroless $\mathrm{Ni}-\mathrm{P}$ films.

\begin{tabular}{lccc}
\hline Bath chemistry $\left(\mathrm{g} \cdot \mathrm{L}^{-1}\right)$ & Value & Plating variables & Value \\
\hline $\mathrm{NiSO}_{4}$ & $15 \sim 50$ & $\mathrm{pH}$ & $8 \sim 12$ \\
$\mathrm{NaH}_{2} \mathrm{PO}_{2}$ & $10 \sim 40$ & Temperature $\left(T,{ }^{\circ} \mathrm{C}\right)$ & $50 \sim 90$ \\
$\mathrm{Na}_{3} \mathrm{C}_{6} \mathrm{H}_{5} \mathrm{O}_{7}$ & $10 \sim 40$ & Time $(t$, min $)$ & $15 \sim 90$ \\
\hline
\end{tabular}

\section{Experimental}

The p-type monocrystalline $\mathrm{Si}$ wafers were used as the substrates (size: $10 \times 10 \times 0.2 \mathrm{~mm}$ ). One surface of Si substrate was etched by reactive ion etching process. Yoo et al. [28] have carefully described this process and pointed out that it could be helpful to effectively improve utilization of absorbed light after reactive ion etching process. Prior to plating, the substrate surface was immersed and etched for $30 \mathrm{~s}$ in a diluted $\mathrm{HF}$ solution $\left(\mathrm{HF}: \mathrm{H}_{2} \mathrm{O}=1: 100\right)$ at room temperature in a fume hood and then rinsed and washed with deionized water by a plastic squeeze bottle and finally followed by cleaning with acetone in an ultrasonic bath for 5 min. A small deposition cell was used for the deposition of the Ni-P film on Si substrates. The volume of bath solution was $50 \mathrm{~mL}$. The bath chemistry and operation conditions are listed in Table 1. No additives and stabilizers were used. The plating bath was composed of Ni sulfate as a Ni ion source, sodium hypophosphite as a reducing agent, and sodium citrate as a complexing agent. The bath chemistries were dissolved in deionized water on a magnetic stirring apparatus with a magnetic stir bar. The $\mathrm{pH}$ of the solution was measured by a $\mathrm{pH}$ meter (PHS-3C) and was adjusted to the desired value by adding $5.0 \mathrm{M}$ sodium hydroxide solution at room temperature. A HH-S thermostatic bath was used to control the bath temperature.

The mass variation of the samples before and after each deposition was measured by an analytical balance (FA2004B, resolution $0.1 \mathrm{mg}$ ). The microstructure and morphology of the top surface and fracture surface of the deposits were observed by a scanning electron microscopy (SEM, JSM-6360) operated in a high vacuum mode and electron beam acceleration voltage of $20 \mathrm{kV}$, equipped with the attached liquid-nitrogen-cooled Oxford Si X-ray energy dispersive spectroscopy (EDS) detector. Each sample was tested at three locations, to confirm uniformity and present representative average values.

Thermal stability of the deposit was measured using thermogravimetric analysis and differential scanning calorimetry (TG-DSC, DSC 404F3 A00 Pegasus) applied from room temperature to $650^{\circ} \mathrm{C}$. The high pure nitrogen gas of $20 \mathrm{~mL} \cdot \mathrm{min}^{-1}$ was used as the carrying gas. The vacuum of the working environment was $10^{-4} \mathrm{~Pa}$. The heating rate was $10 \mathrm{~K} \cdot \mathrm{min}^{-1}$.

\section{Results and Discussion}

\subsection{The Influence of Bath Chemistry}

3.1.1. Concentration of $\mathrm{Ni}^{2+}$ Ions. Figure 1 shows the plots of the $\mathrm{P}$ content in the deposit and weight variation of samples 


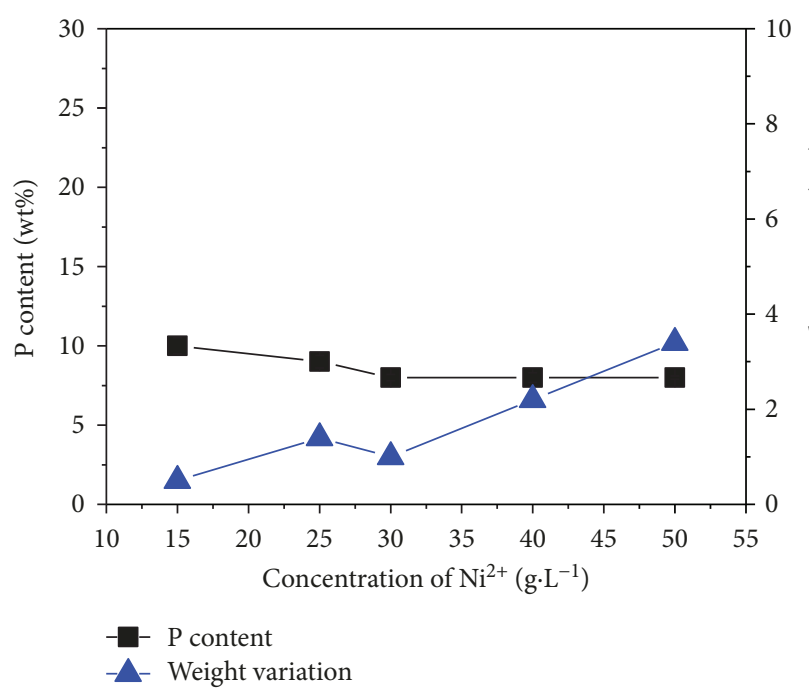

Figure 1: Plots of the $\mathrm{P}$ content in the deposit and weight variations of samples as a function of the concentration of $\mathrm{Ni}^{2+}\left(\mathrm{NaH}_{2} \mathrm{PO}_{2}=20 \mathrm{~g} \cdot \mathrm{L}^{-1}, \quad \mathrm{Na}_{3} \mathrm{C}_{6} \mathrm{H}_{5} \mathrm{O}_{7}=20 \mathrm{~g} \cdot \mathrm{L}^{-1}, \quad\right.$ deposition conditions: $\mathrm{pH}=10.0, T=70^{\circ} \mathrm{C}$, plating time of $15 \mathrm{~min}$ ).

as a function of the concentration of $\mathrm{Ni}^{2+}$. The concentrations of citrate and $\mathrm{H}_{2} \mathrm{PO}_{2}^{-}$ions were the same, $20 \mathrm{~g} \cdot \mathrm{L}^{-1}$. The plating time, $\mathrm{pH}$, and temperature were $15 \mathrm{~min}$, 10.0 , and $70^{\circ} \mathrm{C}$, respectively. When the concentration of $\mathrm{Ni}^{2+}$ was low, about $15 \mathrm{~g} \cdot \mathrm{L}^{-1}$, the $\mathrm{P}$ content was $9 \mathrm{wt} \%$. With the increasing $\mathrm{Ni}^{2+}$ content, the $\mathrm{P}$ content was almost unchanged. However, the weight variation of the sample was slightly increased with the increasing $\mathrm{Ni}^{2+}$ content from 15 to $30 \mathrm{~g} \cdot \mathrm{L}^{-1}$ and then significantly increased with the increase of $\mathrm{Ni}^{2+}$ content. Therefore, the concentration of $\mathrm{Ni}^{2+}$ ions has a significant effect on the deposition rate of the film because of the increase of free $\mathrm{Ni}^{2+}$ in solutions but did not influence $\mathrm{P}$ content in the deposits.

3.1.2. Concentration of $\mathrm{H}_{2} \mathrm{PO}_{2}^{-}$Ions. Figure 2 shows the plots of the $\mathrm{P}$ content in the deposit and weight variation of samples as a function of the concentration of $\mathrm{H}_{2} \mathrm{PO}_{2}^{-}$ions. The concentrations of $\mathrm{Ni}^{2+}$ and citrate ions were $25 \mathrm{~g} \cdot \mathrm{L}^{-1}$ and $20 \mathrm{~g} \cdot \mathrm{L}^{-1}$, respectively. The deposition condition was the same as in Figure 1. With the increasing $\mathrm{H}_{2} \mathrm{PO}_{2}^{-}$content, the $\mathrm{P}$ content and weight variation of sample steadily increased. Abrantes and Correia [23] studied that the concentration of $\mathrm{H}_{2} \mathrm{PO}_{2}^{-}$ion was proportional to deposition rate just in a range. Generally, the very high content of $\mathrm{H}_{2} \mathrm{PO}_{2}^{-}$ions would reduce the deposition rate and produce precipitation that led to the muddy bath, resulting in the unstable electrolytes. Therefore, the complexing agents could prevent precipitation of phosphites and reduce the concentration of free $\mathrm{Ni}^{2+}$ ions and maintain the electrolyte $\mathrm{pH}$ stable.

3.1.3. Concentration of Citric Ions. Figure 3 shows the plots of the $\mathrm{P}$ content in the deposit and weight variations of samples as a function of the concentration of citric ions. The concentrations of $\mathrm{Ni}^{2+}$ and $\mathrm{H}_{2} \mathrm{PO}_{2}^{-}$ions were $25 \mathrm{~g} \cdot \mathrm{L}^{-1}$ and $20 \mathrm{~g} \cdot \mathrm{L}^{-1}$, respectively. The deposition conditions were

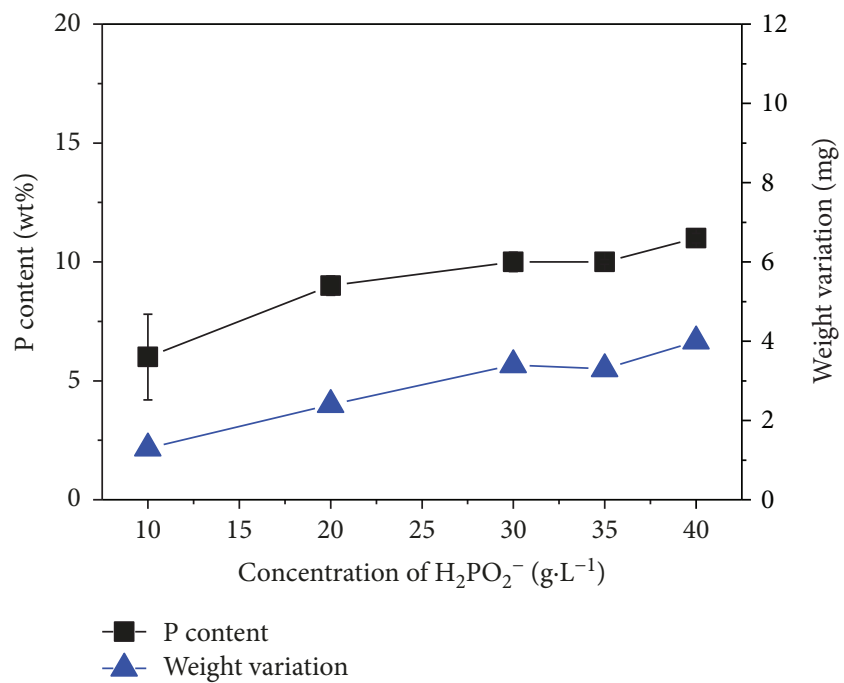

FIgURE 2: Plots of the P content in the deposit and weight variations of samples as a function of the concentration of $\mathrm{H}_{2} \mathrm{PO}_{2}^{-}$ions $\left(\mathrm{NiSO}_{4}=25 \mathrm{~g} \cdot \mathrm{L}^{-1}, \mathrm{Na}_{3} \mathrm{C}_{6} \mathrm{H}_{5} \mathrm{O}_{7}=20 \mathrm{~g} \cdot \mathrm{L}^{-1}\right.$, deposition conditions: $\mathrm{pH}=10.0, T=70^{\circ} \mathrm{C}$, plating time of $15 \mathrm{~min}$ ).

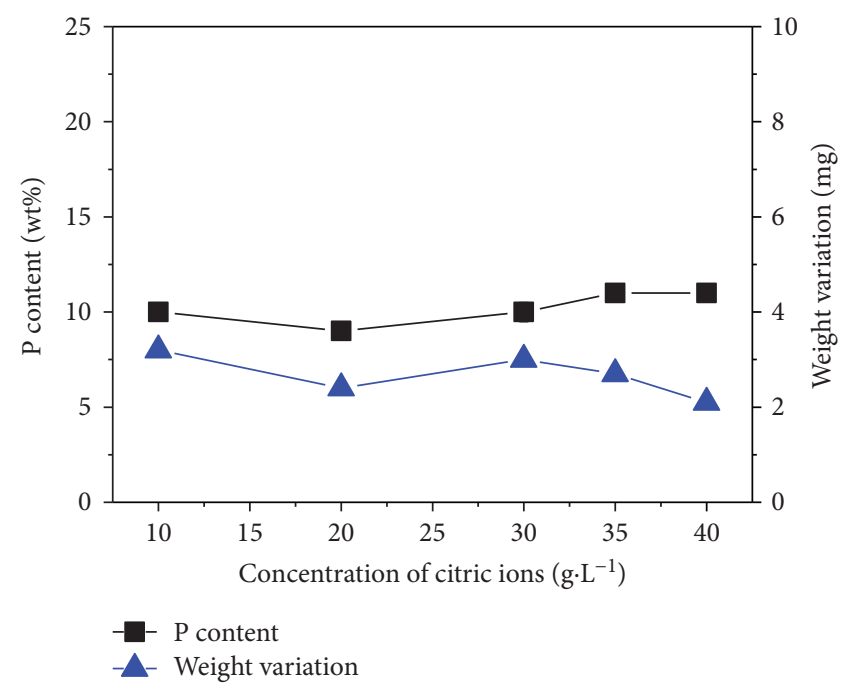

Figure 3: Plots of the P content in the deposit and weight variations of samples as a function of the concentration of citric ions $\left(\mathrm{NiSO}_{4}=25 \mathrm{~g} \cdot \mathrm{L}^{-1}, \mathrm{NaH}_{2} \mathrm{PO}_{2}=20 \mathrm{~g} \cdot \mathrm{L}^{-1}\right.$, the deposition conditions: $\mathrm{pH}=10, T=70^{\circ} \mathrm{C}$, plating time $=15 \mathrm{~min}$ ).

the same as in Figure 1. The P content in the film was not changed significantly and was nearly maintained at a constant value of $10 \mathrm{wt} \%$. When the concentration of citric ions was between 10 and $20 \mathrm{~g} \cdot \mathrm{L}^{-1}$, the weight variation decreased and then increased at the concentration of citric ions about $20-30 \mathrm{~g} \cdot \mathrm{L}^{-1}$ and at other scope was also decreased. The whole tendency of weight variation was declined. The $\mathrm{Ni}$-citrate complexes could decrease in the deposition rate of Ni-P films. It was indicated that the deposition rate of $\mathrm{Ni}$ is proportional to the rate at which the $\mathrm{Ni}$ complex dissociates to form free $\mathrm{Ni}^{2+}$ ion. Thus, the electrolessplating rate is inversely proportional to the stability constant of complexing ion. 


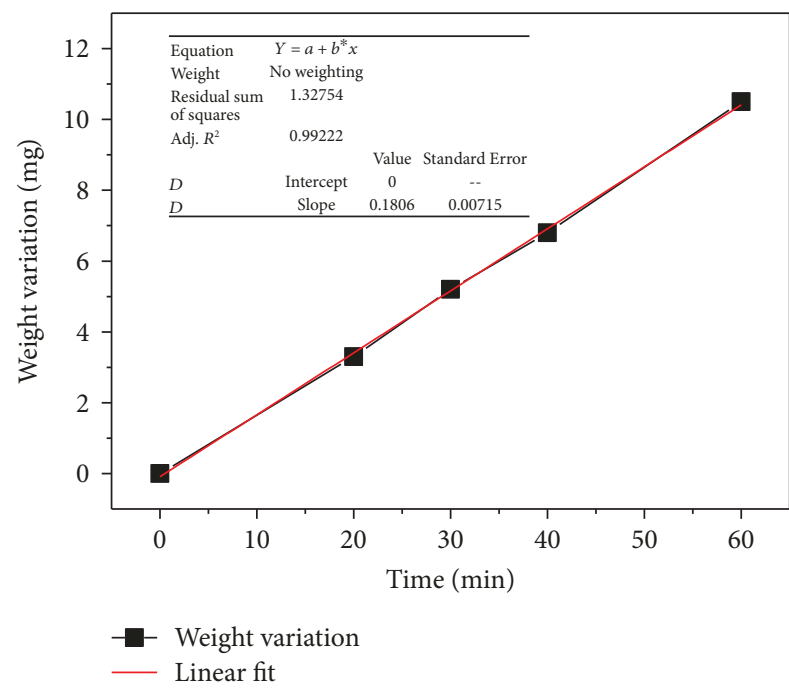

(a)

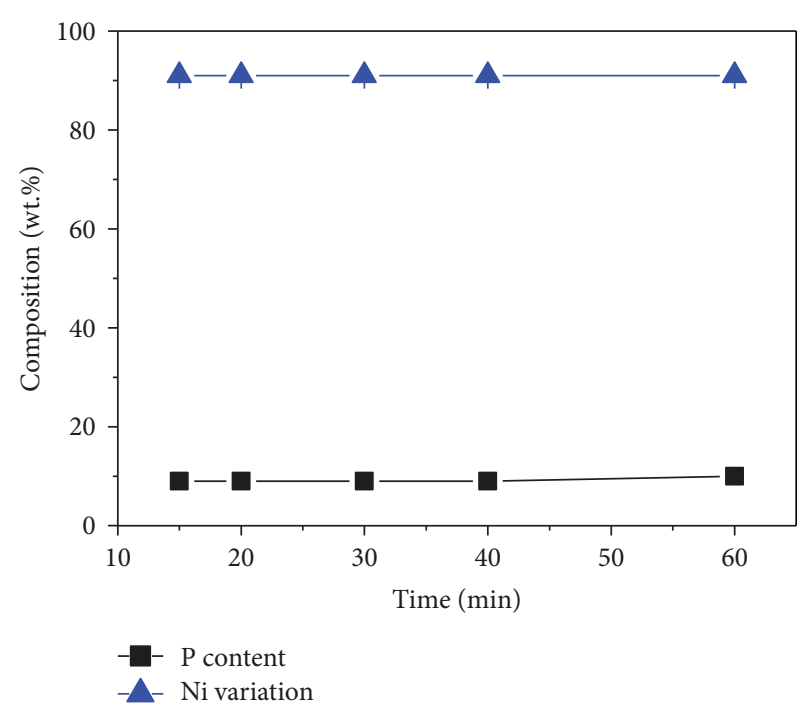

(b)

FIGURE 4: Weight variation of samples (a) and chemical composition of the deposits (b) as a function of plating time $\left(\mathrm{NiSO}_{4}=25 \mathrm{~g} \cdot \mathrm{L}^{-1}\right.$, $\left.\mathrm{NaH}_{2} \mathrm{PO}_{2}=40 \mathrm{~g} \cdot \mathrm{L}^{-1}, \mathrm{Na}_{3} \mathrm{C}_{6} \mathrm{H}_{5} \mathrm{O}_{7}=20 \mathrm{~g} \cdot \mathrm{L}^{-1}, \mathrm{pH}=9.0, T=70^{\circ} \mathrm{C}\right)$.

\subsection{The Influence of Plating Variables}

3.2.1. Deposition Time. Figure 4 shows the plots of deposition time on the function of the gained mass of the sample and the chemical composition of the deposits. The concentrations of $\mathrm{Ni}^{2+}, \mathrm{H}_{2} \mathrm{PO}_{2}^{-}$, and citric ions were $25 \mathrm{~g} \cdot \mathrm{L}^{-1}, 40 \mathrm{~g} \cdot \mathrm{L}^{-1}$, and $20 \mathrm{~g} \cdot \mathrm{L}^{-1}$, respectively. The $\mathrm{pH}$ and temperature were 9.0 and $70^{\circ} \mathrm{C}$, respectively. Observed from Figure $4(\mathrm{a})$, the gained mass displayed a linear dependence on deposition time. The linear equation is $Y=0.18 X$, where $X$ and $Y$ represent the deposition time and the gained mass, respectively. The adjusted $R^{2}$ value of the fitted line is $\sim 0.99$. The deposition rate of the film was $0.18 \mathrm{mg} \cdot \mathrm{min}^{-1}$. As the plating time is increased, the chemical composition of the deposits was almost unchanged. The $\mathrm{P}$ content was nearly maintained at a value of $10 \mathrm{wt} \%$.

3.2.2. Electrolyte $p H$. Figure 5 shows the plots of weight variation of sample and the $\mathrm{P}$ content in the deposits as a function of electrolyte $\mathrm{pH}$. The bath chemistry was the same as in Figure 4. The plating time and temperature were $30 \mathrm{~min}$ and $70^{\circ} \mathrm{C}$, respectively. The change of $\mathrm{pH}$ had a significant impact on the chemical composition and the weight variation of the sample. When the $\mathrm{pH}$ was low, at 8.0, the deposition rate was close to zero for the $15 \mathrm{~min}$ deposition time. The gained weight slightly increased and then decreased. The gained weight reached a maximal value of $1.5 \mathrm{mg}$ at $\mathrm{pH}=10.0$. However, the $\mathrm{P}$ content in the deposits increased with increasing electrolyte $\mathrm{pH}$. Abrantes and Correia [29] studied that an increase of $\mathrm{P}$ content with $\mathrm{pH}$ was observed in alkaline solutions above $\mathrm{pH}$ of 8 , accompanied by a decrease in plating rate. Schlesinger [30] observed that raising bath $\mathrm{pH}$ affected the deposition rate of the film, and alkaline baths tended to have a higher deposition rate with the concomitant result of decreased stability.

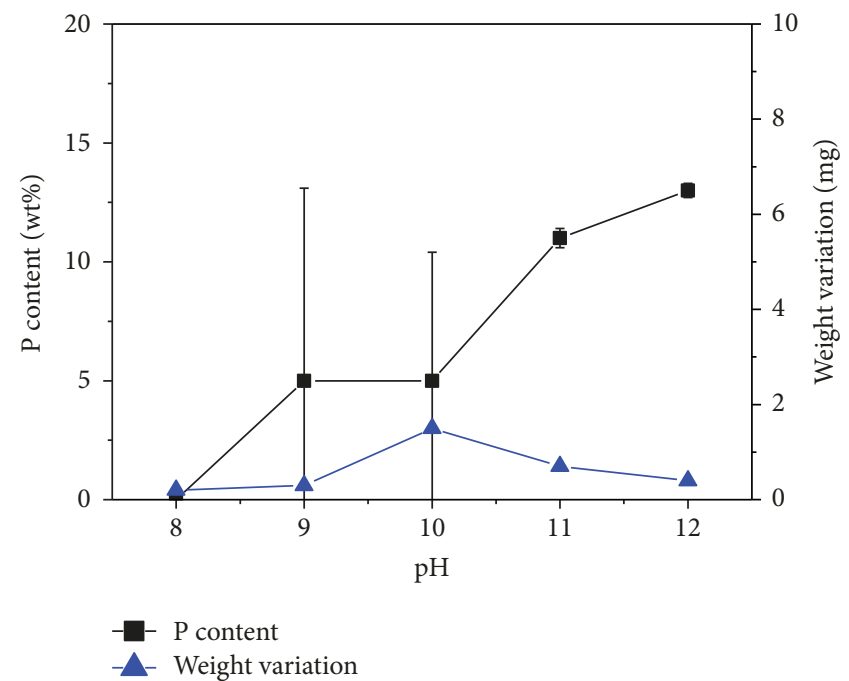

FIgUre 5: Plots of the $\mathrm{P}$ content in the deposit and weight variations of samples as a function of the $\mathrm{pH}\left(\mathrm{NiSO}_{4}=25 \mathrm{~g} \cdot \mathrm{L}^{-1}\right.$, $\mathrm{NaH}_{2} \mathrm{PO}_{2}=40 \mathrm{~g} \cdot \mathrm{L}^{-1}, \quad \mathrm{Na}_{3} \mathrm{C}_{6} \mathrm{H}_{5} \mathrm{O}_{7}=20 \mathrm{~g} \cdot \mathrm{L}^{-1}, \quad T=70^{\circ} \mathrm{C}$, plating time $=30 \mathrm{~min}$ ).

3.2.3. Bath Temperature. Figure 6 shows the plots of weight variation of sample and the $\mathrm{P}$ content in the deposits as a function of bath temperature. The bath chemistry was the same as in Figure 4. The deposition time and bath $\mathrm{pH}$ were $30 \mathrm{~min}$ and 9.0, respectively. When the bath temperature was about $50^{\circ} \mathrm{C}$, the $\mathrm{P}$ content in the deposits was $0 \mathrm{wt} \%$. It is indicated that the reduction of $\mathrm{Ni}$ could not occur at low plating temperature. With increasing deposition temperature from 60 to $90^{\circ} \mathrm{C}$, the $\mathrm{P}$ content in the deposits was increased significantly. The gained weight reached a maximal value at $T=80^{\circ} \mathrm{C}$. Therefore, the bath temperature could affect the chemical composition and deposition rate 


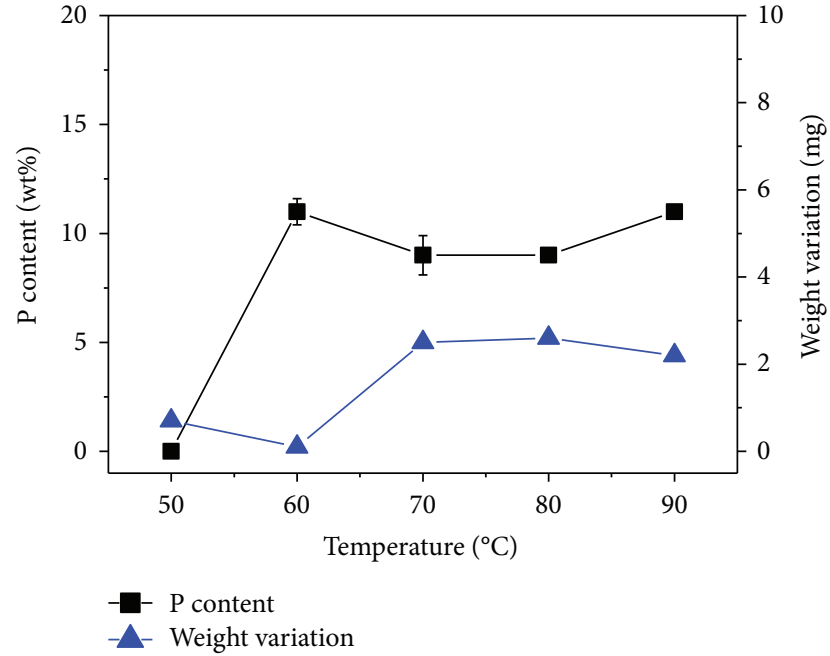

Figure 6: Plots of the $\mathrm{P}$ content in the deposit and weight variations of samples as a function of the temperature $\left(\mathrm{NiSO}_{4}=\right.$ $25 \mathrm{~g} \cdot \mathrm{L}^{-1}, \mathrm{NaH}_{2} \mathrm{PO}_{2}=40 \mathrm{~g} \cdot \mathrm{L}^{-1}, \mathrm{Na}_{3} \mathrm{C}_{6} \mathrm{H}_{5} \mathrm{O}_{7}=20 \mathrm{~g} \cdot \mathrm{L}^{-1}, \mathrm{pH}=9$, plating time $=30 \mathrm{~min}$ ).

of the film. The increase of temperature could result in the increase in the rates of both diffusion and charge transfer. Bath temperature is one of the most important factors affecting the kinetics or rate of the deposition process. However, the bath solution probably contained different complexes; the equilibrium constant could also change with the increase of the temperature.

3.3. Film Characterization. The bath composition and characteristics of representative samples for discussion are listed in Table 2. Figure 7 shows the SEM images of the top surface of the substrate and films, corresponding to the bath composition for the deposition of the films shown in Table 2. Figure 7(a) shows the SEM image of the top surface of the substrate. After reactive ion etching process, the rough surface was composed of pyramid shape structure, which could be helpful to effectively enhance the bonding strength of the film and the substrate.

Figure 7(b) presents the SEM image of the top surface of sample number 14 . The electrolyte composition: $25 \mathrm{~g} \cdot \mathrm{L}^{-1}$ $\mathrm{Ni}^{2+}, 20 \mathrm{~g} \cdot \mathrm{L}^{-1} \mathrm{Cit}^{-}$, and $40 \mathrm{~g} \cdot \mathrm{L}^{-1} \mathrm{H}_{2} \mathrm{PO}_{2}^{-}$. The plating conditions: $T=70^{\circ} \mathrm{C}, \mathrm{pH}=10.0$, and plating time of $15 \mathrm{~min}$. The surface was not dense. Many large particles and small aggregates were formed on the surface. The diameters of the particles are in the range of 0.8 to $3.2 \mu \mathrm{m}$. Two or three particles met and coalesced each other to form a compact particle. It can be observed that there are some coalesced lines between the particles. However, there are some visible big gaps between the round shape particles, and other part particles are squeezed against each other to form a compact layer.

Figure 7(c) shows the SEM image of top surface of sample number 19. The composition of the electrolyte and plating conditions were the same as in Figure 7(b), except that the concentration of $\mathrm{H}_{2} \mathrm{PO}_{2}^{-}$and $\mathrm{pH}$ was decreased to $20 \mathrm{~g} \cdot \mathrm{L}^{-1}$ and 9.0, respectively. The deposit was made of aggregated ultrafine particles and assumed a sponge-like structure. This feature morphology was directly related to the abundant nucleation during the plating process. There are some void spaces inside the clusters of deposits.

Figure 7(d) shows the SEM image of the top surface of sample number 21 . The composition of the electrolyte and plating conditions were the same as in Figure 7(c), except that the $\mathrm{pH}$ of the bath was increased to 12.0. The surface was rough. The deposit was composed of the pyramid structure, which could be influenced by the surface morphology of the substrate. A pyramid particle was covered around by many nanosized particles. The valleys between the pyramid particles were also deposited by small "layer-layer" pyramid aggregates with nanoparticles. The electrolyte $\mathrm{pH}$ has a significant effect on the morphology, composition, and structure of the Ni-P films.

Figure 7(e) shows the SEM image of the top surface of sample number 23. The composition of the electrolyte and plating conditions were the same as in Figure 7(b), except that the temperature and $\mathrm{pH}$ were $60^{\circ} \mathrm{C}$ and 9.0 , respectively. The surface was relatively dense, but some pores were present on the surface. Furthermore, some irregular-shaped aggregates with small spherical particles were formed on the top surface of the underlayer. In this work, Si substrate was not done by a sensitizing process; the $\mathrm{Ni}$ nucleation on the surface of the substrate was limited due to self-activation. The competition between the initial nucleation rate and the film growth rate occurred during electroless deposition. However, the film growth rate is much faster than the initial nucleation rate of the deposits at the low plating temperature and short plating time.

Figure 7(f) shows the SEM image of the top surface of sample number 25 . The composition of the electrolyte and plating conditions were the same as in Figure 7(d), except that bath temperature was increased to $90^{\circ} \mathrm{C}$. The deposit was poor; just some large aggregates were formed on the surface of the substrate. However, the substrate was not completely covered by the deposit. At $T=90^{\circ} \mathrm{C}$, the vaporization of the electrolyte was accelerated, which led to the degeneration of the electrolyte. On the other hand, the electrolyte became unstable at high plating temperature.

Figure 8 shows the SEM images of the top surface of the films deposited with different plating times. After the deposition time of $15 \mathrm{~min}$, the surface was composed of small spherical-shaped particles (Figure 8(a)). These spherical particles had the same size, about $1 \mu \mathrm{m}$. The surface was not dense; the pyramid morphology of the substrate could be found under the film. Within the plating time of $15 \mathrm{~min}$, the initial nucleation of the deposit occurred and the small spherical particles began to meet and coalesce each other to form big aggregates and finally to form the deposit with increasing plating time. At $t=30 \mathrm{~min}$, the surface became relatively dense. However, some micropores were found at the top surface (Figure 8(b)). Perhaps, there is no formation of the nuclei particles on the region of micropores. After a long plating time, the surface became dense (Figure 8(c)). There are many large particles squeezed against each other to form a compact layer. Therefore, the plating time of 15 min was not enough to make the nucleation of the film dense. 
TABLE 2: Bath composition and characteristics of selected samples.

\begin{tabular}{lcccccccccc}
\hline Sample & $\mathrm{Ni}^{2+}\left(\mathrm{g} \cdot \mathrm{L}^{-1}\right)$ & $\mathrm{Cit}^{-}\left(\mathrm{g} \cdot \mathrm{L}^{-1}\right)$ & $\mathrm{H}_{2} \mathrm{PO}_{2}^{-}\left(\mathrm{g} \cdot \mathrm{L}^{-1}\right)$ & $t^{\sim}(\mathrm{min})$ & $w^{\wedge}(\mathrm{mg})$ & $\mathrm{T}^{\#}$ & $\mathrm{pH}$ & $\mathrm{Ni}(\mathrm{wt} \%)$ & $\mathrm{P}(\mathrm{wt} \%)$ & $\mathrm{Figure}$ \\
\hline Number 14 & 25 & 20 & 40 & 15 & 4.0 & $70^{\circ} \mathrm{C}$ & 10 & $89 \pm 0.2$ & $11 \pm 0.2$ & $7(\mathrm{~b}), 9(\mathrm{~b}), 9(\mathrm{~d})$ \\
Number 17 & 25 & 20 & 40 & 60 & 11.5 & $70^{\circ} \mathrm{C}$ & 9 & $90 \pm 0.2$ & $10 \pm 0.2$ & $8(\mathrm{a})^{*}, 8(\mathrm{~b})^{* *}, 8(\mathrm{c})$ \\
Number 19 & 25 & 20 & 20 & 15 & 0.3 & $70^{\circ} \mathrm{C}$ & 9 & $95 \pm 5.4$ & $9.3 \pm 0.3$ & $7(\mathrm{c}), 9(\mathrm{a}), 9(\mathrm{c})$ \\
Number 21 & 25 & 20 & 20 & 15 & 0.4 & $70^{\circ} \mathrm{C}$ & 12 & $87 \pm 0.3$ & $13 \pm 0.3$ & $7(\mathrm{~d})$ \\
Number 23 & 25 & 20 & 40 & 15 & 0.1 & $60^{\circ} \mathrm{C}$ & 9 & $89 \pm 0.6$ & $11 \pm 0.6$ & $7(\mathrm{e})$ \\
Number 25 & 25 & 20 & 40 & 15 & 2.2 & $90^{\circ} \mathrm{C}$ & 9 & $89 \pm 0.2$ & $9 \pm 0.2$ & $7(\mathrm{f})$ \\
\hline
\end{tabular}

Note: $w^{\wedge}$ is the mass gain of sample, $t^{\sim}$ is the plating time, $T^{\#}$ is the plating temperature; ${ }^{* * *}$ plating time of 15 min and 30 min, respectively.

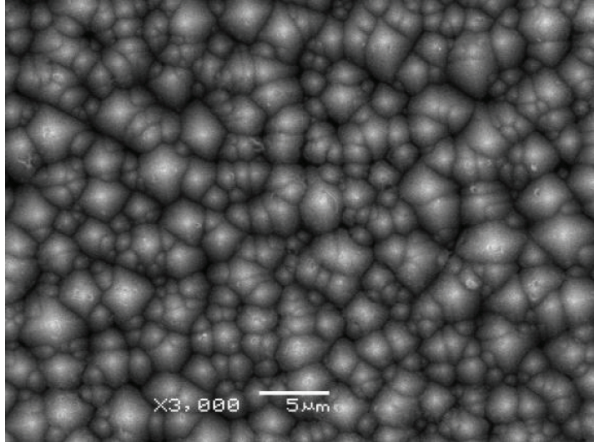

(a)

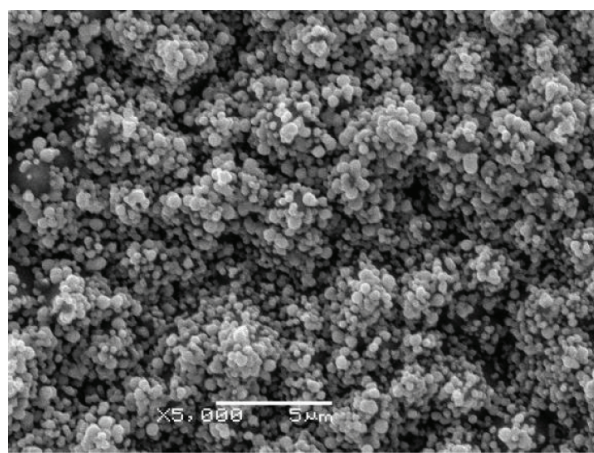

(c)

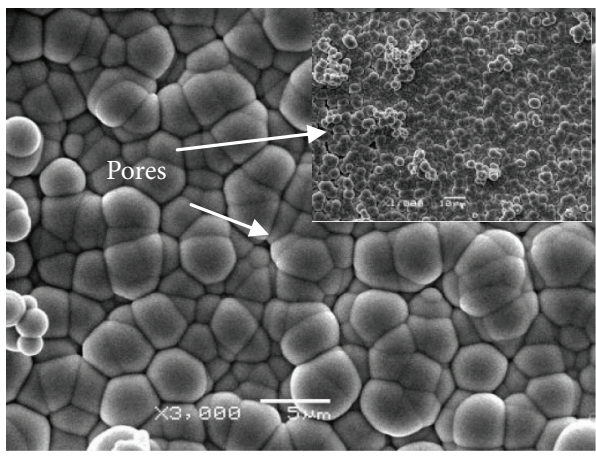

(e)

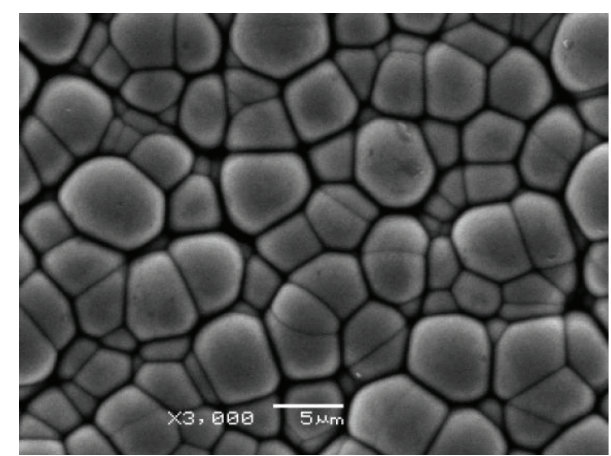

(b)

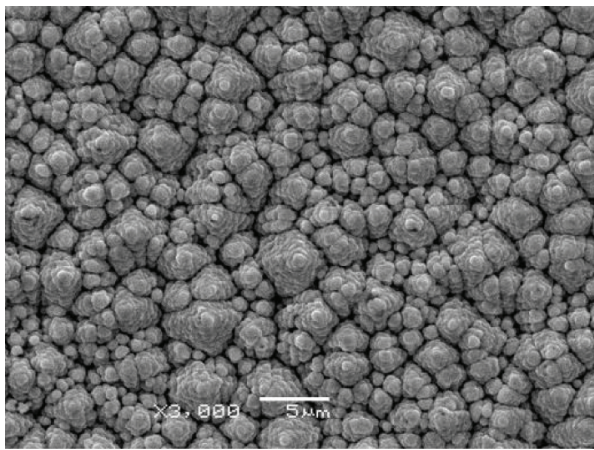

(d)

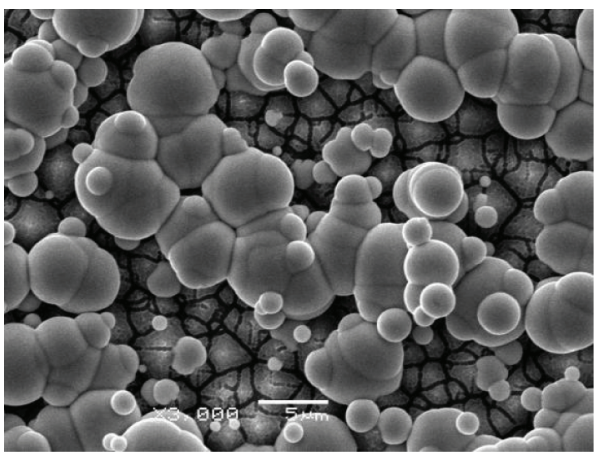

(f)

Figure 7: SEM images of the top surface of the alloy films. The samples are substrate (a), number 14 (b), number 19 (c), number 21 (d), number 23 (e), and number 25 (f).

Figure 9 shows the SEM image and line scanning analysis of the EDS of the fracture surface of sample numbers 19 and 14. From Figure 9(a), the surface of the film was relatively rough. The thickness of the film was about $2 \mu \mathrm{m} \pm 0.5$. It can be seen that the film was dense. There are some obvious little knots at the interface between the substrate and film, indicating that the structure had a sharp interface and produced alloy deposits free of macrodefects. Furthermore, 


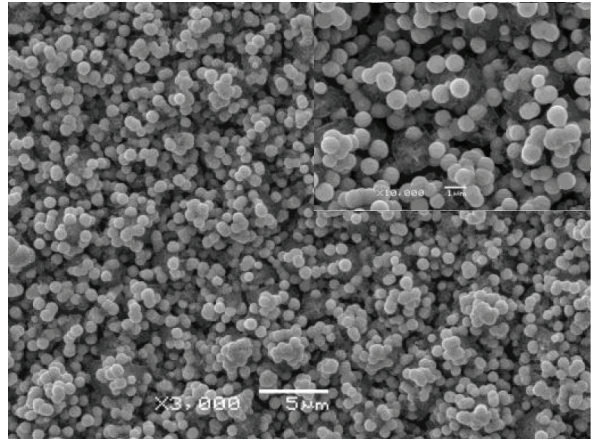

(a)

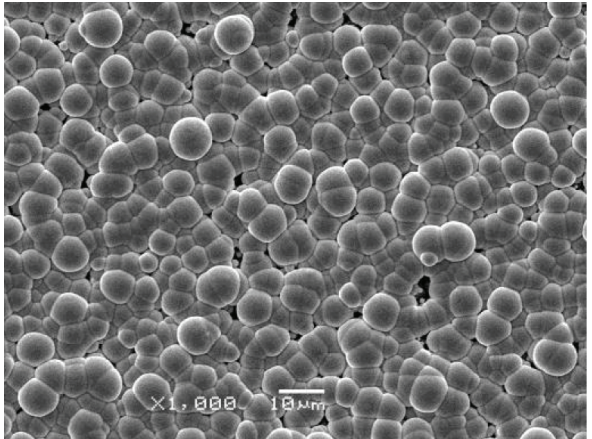

(b)

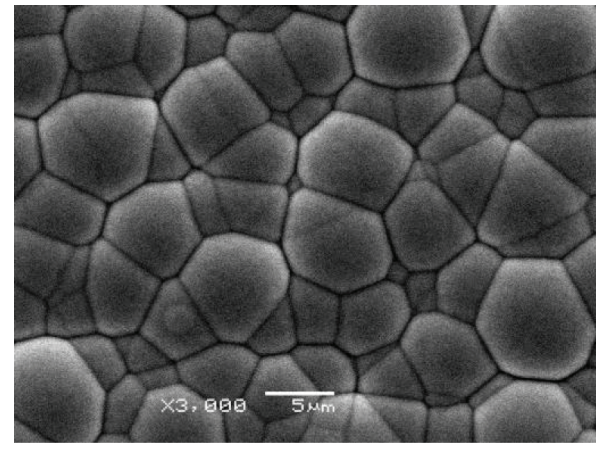

(c)

FIgURE 8: SEM images of the top surface of the alloy films deposited with different plating times: (a) $15 \mathrm{~min}$, (b) $30 \mathrm{~min}$, (c) $60 \mathrm{~min}$ $\left(\mathrm{NiSO}_{4}=25 \mathrm{~g} \cdot \mathrm{L}^{-1}, \mathrm{NaH}_{2} \mathrm{PO}_{2}=40 \mathrm{~g} \cdot \mathrm{L}^{-1}, \mathrm{Na}_{3} \mathrm{C}_{6} \mathrm{H}_{5} \mathrm{O}_{7}=20 \mathrm{~g} \cdot \mathrm{L}^{-1}, \mathrm{pH}=9.0, T=70^{\circ} \mathrm{C}\right)$.

some valleys on the surface of the substrate were not covered by the deposits, which could be from the low nucleation rate of the deposit at the initial stage. Figure 9(c) displays the plot of the chemical composition of the film. The content of $\mathrm{Ni}$ and $\mathrm{P}$ in the film was uniform, and the content of $\mathrm{Ni}$ was higher than that of $\mathrm{P}$.

Figure 9(b) displays the SEM images of the cross-section of the film (sample number 14). The thickness of the film was about $18 \pm 0.1 \mu \mathrm{m}$. The film exhibited good adherence to the Si substrate, with no evidence of delamination. Moreover, it can be observed that the boundary between the layer and the substrate is visible. There are many big particles like some nodules infiltrated into Si substrate, which could be helpful to improve the bonding between the deposit and the substrate. The EDS line profile showed that $\mathrm{Ni}$ concentration has a sharp peak with a sudden increase at the interface between the deposit and the substrate (Figure 9(d)), which is assertive evidence to prove that $\mathrm{Ni}$ nuclei particles were formed preferentially in the initial nucleation stage.

In the alkaline solutions, the chemical reactions for electroless $\mathrm{Ni}-\mathrm{P}$ film would be expressed by the following equations, reported by Zhang et al. [31]:

$$
\begin{gathered}
\mathrm{H}_{2} \mathrm{PO}_{2}^{-}+2 \mathrm{OH}^{-} \longrightarrow \mathrm{H}^{-}+\mathrm{HPO}_{3}^{2-}+\mathrm{H}_{2} \mathrm{O} \\
\mathrm{Ni}^{2+}+2 \mathrm{H}^{-} \longrightarrow \mathrm{Ni}^{0}+\mathrm{H}_{2} \uparrow \\
\mathrm{H}_{2} \mathrm{PO}_{2}^{-}+\mathrm{H}^{-} \longrightarrow 2 \mathrm{OH}^{-}+\mathrm{P}+\frac{1}{2} \mathrm{H}_{2} \uparrow \\
\mathrm{H}_{2} \mathrm{O}+\mathrm{H}^{-} \longrightarrow \mathrm{OH}^{-}+\mathrm{H}_{2} \uparrow
\end{gathered}
$$

According to (1), (2), (3), and (4), the occurrence of hydrogen evolution was from the water and hydride ions. In this work, the electrolyte $\mathrm{pH}$ has an impact on the chemical composition, top morphology, and deposition rate of electroless Ni-P. Abdel Hamid [32] pointed out that the increase in $\mathrm{pH}$ value for the alkaline solution resulted in the decrease of the deposition rate due to the consumption of $\mathrm{OH}^{-}$ions according to the following:

$$
\mathrm{H}_{2} \mathrm{PO}_{2}^{-}+\mathrm{OH}^{-} \longrightarrow \mathrm{H}_{\mathrm{ads}}+\mathrm{H}_{2} \mathrm{PO}_{3}^{-}+\mathrm{e}^{-}
$$

The hydrogen evolution (6) was from the combination of two $\mathrm{H}$ atoms, at the same time, resulting in the reduction of $\mathrm{Ni}^{2+}$ ions (7).

$$
\begin{gathered}
2 \mathrm{H}_{\mathrm{ads}} \longrightarrow \mathrm{H}_{2} \uparrow \\
2 \mathrm{H}_{\mathrm{ads}}+\mathrm{Ni}^{2+} \longrightarrow \mathrm{N}+2 \mathrm{H}^{+}
\end{gathered}
$$

However, the metal $\mathrm{Ni}$ mainly resulted from the chemical reactions between the $\mathrm{Ni}$ ions and the reductant radicals [29, 33]. The electroless deposition of $\mathrm{Ni}-\mathrm{P}$ alloy is a complex autocatalytic process. The reducing agent, $\mathrm{H}_{2} \mathrm{PO}_{2}^{-}$ions, participates in oxidation and reduction reactions. Hsu et al. [34] reported that $\mathrm{H}_{2} \mathrm{PO}^{-}$ions absorbed on the catalytic surface reacted with $\mathrm{H}_{2} \mathrm{O}$ to form free $e^{-}$, $\mathrm{H}_{2} \mathrm{PO}_{3}^{-}$, and $\mathrm{H}^{+}$ions:

$$
\begin{gathered}
\mathrm{H}_{2} \mathrm{PO}_{2}^{-}+\mathrm{H}_{2} \mathrm{O} \longrightarrow \mathrm{H}_{2} \mathrm{PO}_{3}^{-}+2 \mathrm{e}^{-}+2 \mathrm{H}^{+} \\
\mathrm{Ni}^{2+}+2 \mathrm{e}^{-} \longrightarrow \mathrm{Ni}^{0}
\end{gathered}
$$




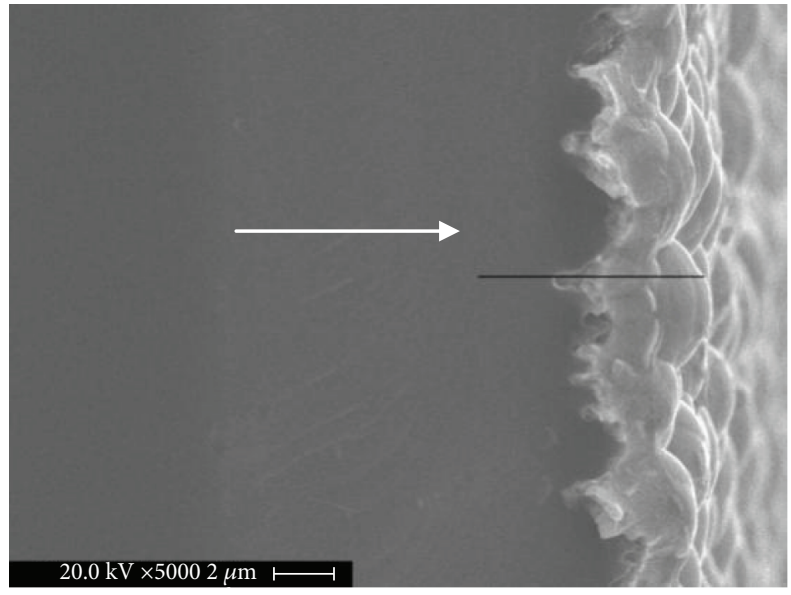

(a)

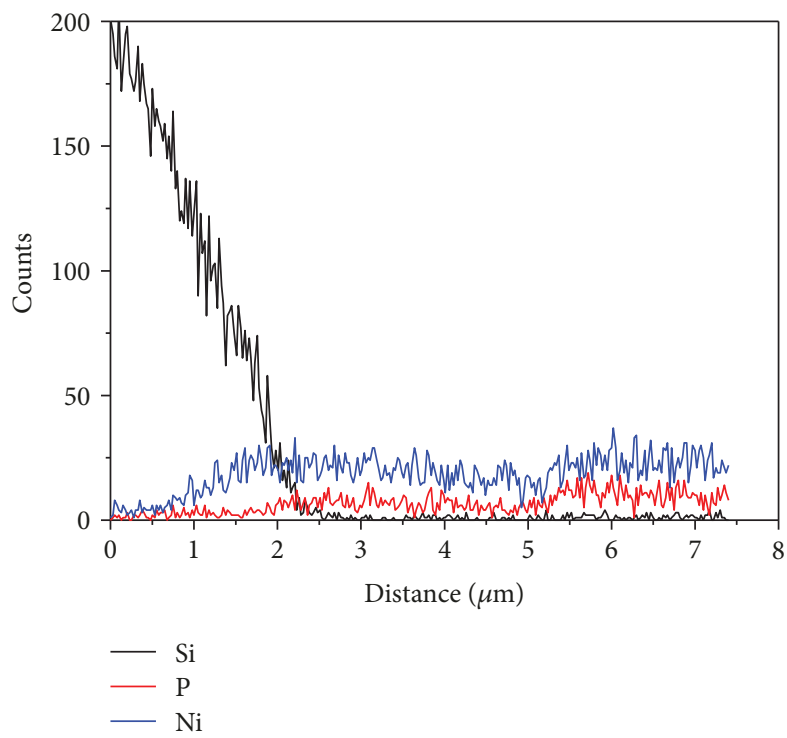

(c)

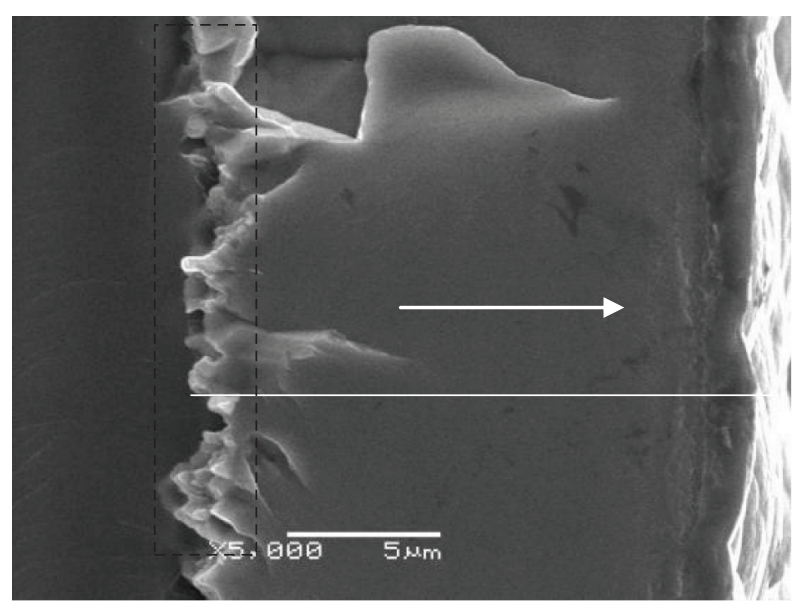

(b)

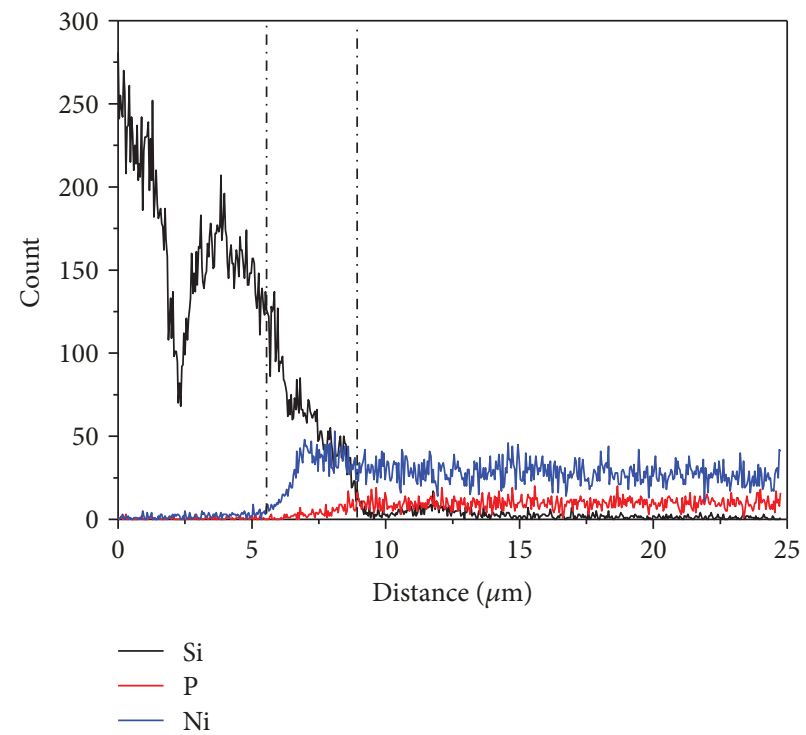

(d)

FIGURE 9: SEM image (a,b) and line scanning analysis (c, d) of the EDS of the fracture surface of sample numbers 19 (a, c) and 14 (b, d) deposited for $90 \mathrm{~min}$.

However, the Si wafers could be oxidized in the alkaline solution at the plating conditions, such as bath temperature. The chemical reaction was as follows:

$$
\mathrm{Si}+2 \mathrm{OH}^{-} \longrightarrow \mathrm{SiO}_{2}+\mathrm{H}_{2} \uparrow+2 \mathrm{e}^{-}
$$

Hsu et al. [34] found that the galvanic displacement reaction occurred as the Si substrate was immersed in the aqueous alkaline solution. It is a spontaneous reaction, which for $\mathrm{Ni}$ deposition can be expressed as follows:

$$
2 \mathrm{Ni}^{2+}+\mathrm{Si} \longrightarrow 2 \mathrm{Ni}^{0}+\mathrm{Si}^{4+}
$$

During this spontaneous reaction, the Si substrate surface was oxidized and became a catalytic surface inducing further codeposition of Ni-P film. Therefore, the oxidation and reduction reactions of $\mathrm{H}_{2} \mathrm{PO}_{2}^{-}$ions began to occur, followed by codeposition of Ni-P film. Oskam et al. [35] suggested that three mechanisms of electroless metal deposition on $\mathrm{Si}$ wafer (i) holes injected from metal ions $\left(\mathrm{M}^{+}\right)$were consumed by oxidation of the $\mathrm{Si}$, (ii) injected holes were captured by an electron donor in the solution, and (iii) metal ions are catalytically reduced at an existing metal nucleus involving electrons donated by a reducing agent in the solution.

In this study, the $\mathrm{P}$ content and weight variation of the sample steadily increased with increasing $\mathrm{H}_{2} \mathrm{PO}_{2}^{-}$content. The reducing agent was added and the nucleated Ni particles were produced, and then $\mathrm{Ni}-\mathrm{P}$ film was grown rapidly. Coincidentally with $\mathrm{Ni}$ reduction, $\mathrm{H}_{2} \mathrm{PO}_{2}^{-}$ions were reduced to elemental $\mathrm{P}$ and oxidized to $\mathrm{H}_{2} \mathrm{PO}_{3}^{-}$as the following reaction:

$$
2 \mathrm{H}_{2} \mathrm{PO}_{2}^{-} \longrightarrow \mathrm{H}_{2} \mathrm{PO}_{3}^{-}+\mathrm{P}+\mathrm{OH}^{-}+\frac{1}{2} \mathrm{H}_{2}
$$

Island growth was evident and remarkable sparse sphere particle nucleation was present. Then, islands grew and then met one another and drove to form a continuous film. Adhesion of the Ni-P film with Si substrate is naturally poor 


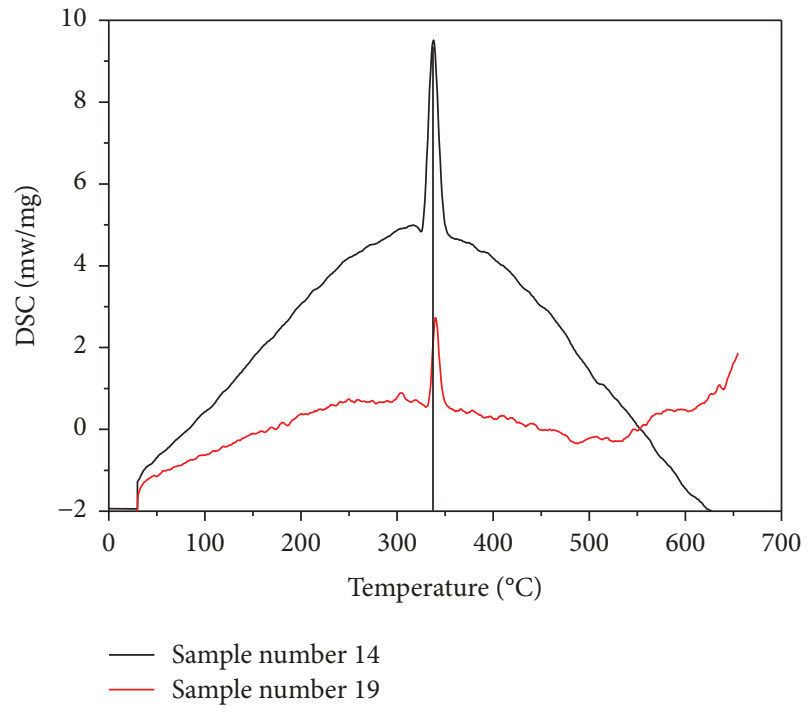

Figure 10: DSC curves of the Ni-P films from sample numbers 19 and 14 at the same heating rate of $10 \mathrm{~K} \cdot \mathrm{min}^{-1}$.

because of the sparsely distributed Ni nuclei particles in the initial nucleation stage (see Figures 7(b), 8(a), and 9(b)). Nuclei are firstly bonded to the substrate surface. In the initial nucleation stage, the nucleation rate of $\mathrm{Ni}$ was insufficient, which could cause a weak adhesion between the Ni-P layer and Si substrate [24]. Although the film growth was so fast that the dense surface of the deposit was formed, lack of attachment areas and sites on the Si wafer caused the Ni-P deposits to peel off easily. On the other hand, the adhesion of the deposit may be poor due to the simultaneous dissolution of the Si wafer and deposition of the Ni-P [36].

3.4. Thermal Stability. Figure 10 shows the DSC curves of the Ni-P films from sample numbers 19 and 14 at the same heating rate of $10 \mathrm{~K} \cdot \mathrm{min}^{-1}$. The $\mathrm{P}$ content for sample numbers 19 and 14 was $9.3 \pm 0.3 \mathrm{wt} \%$ and $11 \pm 0.2 \mathrm{wt} \%$, respectively. Schlesinger [30] reviewed electroless nickel, alloy, composite, and nanocoatings and pointed out low-P deposits (less than $5 \mathrm{wt} \% \mathrm{P}$ ) are crystalline and exhibit good wear resistance but relatively poor corrosion resistance in a chloride environment. Medium-P deposits (6-9 wt\% P) have a smaller crystalline size, whereas high-P deposits (more than $10 \mathrm{wt} \% \mathrm{P}$ ) exist mainly as a metallic glass. Therefore, the sample numbers 19 and 14 were medium- and high-P deposits, respectively. An exothermic peak is detected with the crystallization peak temperature located at $339^{\circ} \mathrm{C}$ for high-P deposit and $341^{\circ} \mathrm{C}$ for medium-P deposit, respectively. The thermal stability of the medium-P film is better than that of the high-P deposit. The film is a mixture of amorphous and microcrystalline $\mathrm{Ni}$ at low- and medium-P deposit, but it is fully amorphous when the $\mathrm{P}$ content is high. Sampath and Nair [37] found that the crystallite size decreases with increasing $\mathrm{P}$ content in the deposit. Therefore, the crystallinity of the electroless Ni-P film for sample number 19 was higher than that for sample number 14. Sudagar et al. [36] and Cheng et al. [38] also reported the same result and pointed out that formation of microcrystalline phase could improve the thermal stability of electroless Ni-P film. Because the microcrystalline phase with ordered structure is more stable than the amorphous matrix in which the atoms are disordered and these stable microcrystalline phases inhibit the movement of some $\mathrm{Ni}$ or $\mathrm{P}$ atoms in amorphous matrix, so these disordered atoms need a higher temperature to finish the crystalline process.

\section{Conclusions}

In this work, the Ni-P film was electrolessly plated on the surface of p-type monocrystalline Si wafers in the alkaline bath solutions. The influences of bath chemistry and deposition variables on the chemical composition, morphology, deposition rate, and thermal stability of the Ni-P deposits were investigated in detail. The following results have been shown:

(1) The concentration of $\mathrm{Ni}^{2+}$ ions has an effect on the deposition rate of the film because of the increase of free $\mathrm{Ni}^{2+}$ in solutions but did not influence $\mathrm{P}$ content in the deposits. With the increasing $\mathrm{H}_{2}$ $\mathrm{PO}_{2}^{-}$content, the $\mathrm{P}$ content and deposition rate steadily increased. With the increasing citric acid content, the $\mathrm{P}$ content in the film kept stable at a value of $10 \mathrm{wt} \%$. However, the change tendency of weight variation was declined. The Ni-citrate complexes resulted in the decrease in the rate of the film deposition.

(2) A bath was composed of $25 \mathrm{~g} \cdot \mathrm{L}^{-1} \mathrm{Ni}^{2+}, 40 \mathrm{~g} \cdot \mathrm{L}^{-1} \mathrm{H}_{2}$ $\mathrm{PO}_{2}^{-}$, and $20 \mathrm{~g} \cdot \mathrm{L}^{-1}$ citric ions. The $\mathrm{pH}$ and temperature were 9.0 and $70^{\circ} \mathrm{C}$, respectively. The deposition rate of the deposit was $1.327 \mathrm{mg} \cdot \mathrm{min}^{-1}$. As the plating time increased, the $\mathrm{P}$ content had little or no change.

(3) The $\mathrm{pH}$ and temperature had an impact on the chemical composition and the deposition rate of the films. When the $\mathrm{pH}$ was low, at 8.0, the deposition rate was close to zero. The gained weight slightly increased and then decreased with increasing $\mathrm{pH}$. The gained mass reached a maximal value of $1.5 \mathrm{mg}$ at $\mathrm{pH}=10.0$. The $\mathrm{P}$ content increased with increase in $\mathrm{pH}$. As the temperature was about $50^{\circ} \mathrm{C}$, the reduction of $\mathrm{Ni}$ could not occur. With increasing temperature from 60 to $90^{\circ} \mathrm{C}$, the $\mathrm{P}$ content increased significantly. The deposition rate was greatly changed and the gained mass reached a maximal value at the temperature of $80^{\circ} \mathrm{C}$.

(4) The film growth rate is much faster than the initial nucleation rate of the deposits. Island growth was evident, and remarkable sparse sphere particle nucleation was present. The concentration of $\mathrm{H}_{2} \mathrm{PO}_{2}^{-}, \mathrm{pH}$, temperature, and plating time had a significant influence the surface morphologies of the deposits. With increasing plating time, the surface morphology with small spherical-shaped particles was changed to the dense surface. 
(5) The thermal stability of the medium-P film was better than that of the high-P deposit. An exothermic peak is detected with the crystallization peak temperature located at $339^{\circ} \mathrm{C}$ for high-P deposit and $341^{\circ} \mathrm{C}$ for medium-P deposit, respectively.

\section{Data Availability}

The data used to support the findings of this study are available from the corresponding author upon request.

\section{Conflicts of Interest}

The authors declare that they have no conflicts of interest.

\section{Acknowledgments}

This work has been supported by the Natural Science Foundation of Jiangsu Province (Grant no. BK20150260) and the funding of Changzhou High Technology Research Key Laboratory of Mould Advanced Manufacturing (Grant no. CM20173001). The authors gratefully acknowledge the Testing Center of Changzhou University for providing SEM/EDS facilities.

\section{References}

[1] C. W. Tsao, Z. J. Yang, and C. W. Chung, "Preparation of nanostructured silicon surface for mass spectrometry analysis by an all-wet fabrication process using electroless metal deposition and metal assisted etching," International Journal of Mass Spectrometry, vol. 321-322, pp. 8-13, 2012.

[2] T. P. N. Nguyen, R. Dufour, V. Thomy, V. Senez, R. Boukherroub, and Y. Coffinier, "Fabrication of superhydrophobic and highly oleophobic silicon-based surfaces via electroless etching method," Applied Surface Science, vol. 295, pp. 38-43, 2014.

[3] Y. Sun, R. S. Li, and H. N. Sing, "Room-temperature operation of silicon single-electron transistor fabricated using optical lithography," IEEE Transactions on Nanotechnology, vol. 10, no. 1, pp. 96-98, 2011.

[4] Y. Sun and H. N. Sing, "Effect of oxidation-induced tensile strain on gate-all-around silicon-nanowire-based singleelectron transistor fabricated using deep-UV lithography," IEEE Transactions on Nanotechnology, vol. 10, no. 6, pp. 1214-1216, 2011.

[5] M. Farhoud, M. Hwang, H. I. Smith, M. L. Schattenburg, and J. M. Bae, "Fabrication of large area nanostructured magnets by interferometric lithography," IEEE Transactions on Magnetics, vol. 34, no. 4, pp. 1087-1089, 2002.

[6] M. J. Schöning, A. Kurowski, M. Thust, P. Kordos, J. W. Schultze, and H. Lüth, "Capacitive microsensors for biochemical sensing based on porous silicon technology," Sensors and Actuators B: Chemical, vol. 64, no. 1-3, pp. 59-64, 2000.

[7] M. Lehmann, W. Baumann, M. Brischwein, R. Ehret, M. Kraus, and A. Schwinde, "Non-invasive measurement of cell membrane associated proton gradients by ion-sensitive field effect transistor arrays for microphysiological and bioelectronical applications," Biosensors \& Bioelectronics, vol. 15, no. 3-4, pp. 117-124, 2000.
[8] E. Webb, C. Witt, T. Andryuschenko, and J. Reid, "Integration of thin electroless copper films in copper interconnect metallization," Journal of Applied Electrochemistry, vol. 34, no. 3, pp. 291-300, 2004.

[9] S. Dhar and S. Chakrabarti, "Electroless Ni plating on n- and p-type porous Si for ohmic and rectifying contacts," Semiconductor Science and Technology, vol. 11, no. 8, pp. 1231-1234, 1996.

[10] W. P. Wu, Z. Z. Wang, P. Jiang, and Z. P. Tang, "Effect of electroplating variables on electrodeposition of $\mathrm{Ni}$ rich $\mathrm{Ni}$ - Ir alloys from citrate aqueous solutions," Journal of the Electrochemical Society, vol. 164, no. 14, pp. D985-D993, 2017.

[11] W. P. Wu, J. J. Jiang, P. Jiang, Z. Z. Wang, N. Y. Yuan, and J. N. Ding, "Electrodeposition of nickel-iridium alloy films from aqueous solutions," Applied Surface Science, vol. 434, pp. 307-317, 2018.

[12] X. L. Xiong, Y. Y. Ji, M. W. Xie et al., " $\mathrm{MnO}_{2}-\mathrm{CoP}_{3}$ nanowires array: an efficient electrocatalyst for alkaline oxygen evolution reaction with enhanced activity," Electrochemistry Communications, vol. 86, pp. 161-165, 2018.

[13] X. Q. Ji, R. Zhang, X. F. Shi, A. M. Asiri, B. Z. Zheng, and X. P. Sun, "Fabrication of hierarchical CoP nanosheet@microwire arrays via space-confined phosphidation toward high-efficiency water oxidation electrocatalysis under alkaline conditions," Nanoscale, vol. 10, no. 17, pp. 7941-7945, 2018.

[14] X. Q. Ji, B. P. Liu, X. Ren, X. F. Shi, A. M. Asiri, and X. P. Sun, "P-Doped Ag nanoparticles embedded in N-doped carbon nanoflake: an efficient electrocatalyst for the hydrogen evolution reaction," ACS Sustainable Chemistry \& Engineering, vol. 6, no. 4, pp. 4499-4503, 2018.

[15] T. T. Liu, D. N. Liu, F. L. Qu et al., "Enhanced electrocatalysis for energy-efficient hydrogen production over CoP catalyst with nonelectroactive $\mathrm{Zn}$ as a promoter," Advanced Energy Materials, vol. 7, no. 15, article 1700020, 2017.

[16] Y. C. Chen, Y. C. S. Wu, C. W. Chao, G. R. Hu, and M. S. Feng, "Electroless plating Ni induced crystallization of amorphous silicon thin films," Japanese Journal of Applied Physics, vol. 40, 9A, Part 1, pp. 5244-5246, 2001.

[17] M. Moniruzzaman and S. Roy, "Effect of $\mathrm{pH}$ on electroless $\mathrm{Ni}-\mathrm{P}$ coating of conductive and non-conductive materials," International Journal of Automotive and Mechanical Engineering, vol. 4, pp. 481-489, 2011.

[18] A. Rahman and R. Jayaganthan, "Effect of $\mathrm{pH}$ values on nanostructured Ni-P films," Applied Nanoscience, vol. 5, no. 4, pp. 493-498, 2015.

[19] W. L. Liu, S. H. Hsieh, T. K. Tsai, W. J. Chen, and S. S. Wu, "Temperature and $\mathrm{pH}$ dependence of the electroless $\mathrm{Ni}-\mathrm{P}$ deposition on silicon," Thin Solid Films, vol. 510, no. 1-2, pp. 102-106, 2006.

[20] V. K. Bulasara, H. Thakuria, R. Uppaluri, and M. K. Purkait, "Combinatorial performance characteristics of agitated nickel hypophosphite electroless plating baths," Journal of Materials Processing Technology, vol. 211, no. 9, pp. 1488-1499, 2011.

[21] A. K. Singh, V. K. Bajpai, and C. S. Solanki, "Effect of light on electroless nickel deposition for solar cell applications," Energy Procedia, vol. 54, pp. 763-770, 2014.

[22] J. T. W. Jappes, B. Ramamoorthy, and P. K. Nair, "A study on the influence of process parameters on efficiency and crystallinity of electroless Ni-P deposits," Journal of Materials Processing Technology, vol. 169, no. 2, pp. 308-313, 2005. 
[23] A. A. Ashtiani, S. Faraji, S. A. Iranagh, and A. H. Faraji, "The study of electroless Ni-P alloys with different complexing agents on Ck45 steel substrate," Arabian Journal of Chemistry, vol. 10, pp. S1541-S1545, 2017.

[24] X. Zhang, F. Ren, M. S. Goorsky, and K. N. Tu, "Study of the initial stage of electroless $\mathrm{Ni}$ deposition on $\mathrm{Si}$ (100) substrates in aqueous alkaline solution," Surface and Coating Technology, vol. 201, no. 6, pp. 2724-2732, 2006.

[25] T. Homma, "Transmission electron microscopy study of electroless $\mathrm{NiP}$ and $\mathrm{Cu}$ films at initial deposition stage," Journal of the Electrochemical Society, vol. 138, no. 5, pp. 1269-1274, 1991.

[26] H. W. Xie and B. W. Zhang, "Effects of preparation technology on the structure and amorphous forming region for electroless Ni-P alloys," Journal of Materials Processing Technology, vol. 124, pp. 8-13, 2002.

[27] W. P. Wu and J. J. Jiang, "Effect of plating temperature on electroless amorphous $\mathrm{Ni}-\mathrm{P}$ film on $\mathrm{Si}$ wafers in an alkaline bath solution," Applied Nanoscience, vol. 7, no. 6, pp. 325333, 2017.

[28] J. Yoo, G. Yu, and J. Yi, "Large-area multicrystalline silicon solar cell fabrication using reactive ion etching (RIE)," Solar Energy Materials and Solar Cells, vol. 95, no. 1, pp. 2-6, 2011.

[29] L. M. Abrantes and J. P. Correia, "On the mechanism of electroless Ni-P plating," Journal of the Electrochemical Society, vol. 141, no. 9, pp. 2356-2360, 1994.

[30] M. Schlesinger, "Electroless deposition of nickel," Modern Electroplating, vol. 5, pp. 447-458, 2011.

[31] Y. C. Zhang, N. H. Ru, and X. Rong, Electroplating Handbook, National Defence Industry Press, 2011.

[32] Z. Abdel Hamid, "Mechanism of electroless deposition of Ni-W-P alloys by adding surfactants," Surface and Interface Analysis, vol. 35, no. 6, pp. 496-501, 2003.

[33] H. Iwasa, M. Yokozawa, and I. Teramoto, "Electroless nickel plating on silicon," Journal of the Electrochemical Society, vol. 115 , no. 5, pp. $485-488,1968$.

[34] H. F. Hsu, C. L. Tsai, C. W. Lee, and H. Y. Wu, "Mechanism of immersion deposition of $\mathrm{Ni}-\mathrm{P}$ films on $\mathrm{Si}(100)$ in an aqueous alkaline solution containing sodium hypophosphite," Thin Solid Films, vol. 517, no. 17, pp. 4786-4791, 2009.

[35] G. Oskam, J. G. Long, A. Natarajan, and P. C. Searson, "Electrochemical deposition of metals onto silicon," Journal of Physics D: Applied Physics, vol. 31, no. 16, pp. 1927-1949, 1998.

[36] J. Sudagar, J. Lian, and W. Sha, "Electroless nickel, alloy, composite and nano coatings - a critical review," Journal of Alloys and Compounds, vol. 571, pp. 183-204, 2013.

[37] K. Sampath and K. Nair, "Studies on crystallization of electroless Ni-P deposits," Journal of Materials Processing Technology, vol. 56, no. 1-4, pp. 511-520, 1996.

[38] Y. H. Cheng, Y. Zou, L. Cheng, and W. Liu, "Effect of complexing agents on properties of electroless Ni-P deposits," Materials Science and Technology, vol. 24, no. 4, pp. 457-460, 2008. 


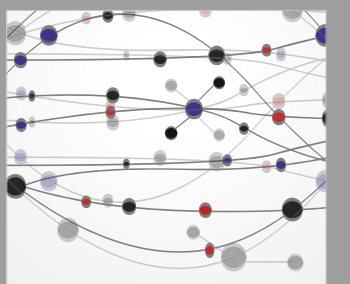

The Scientific World Journal
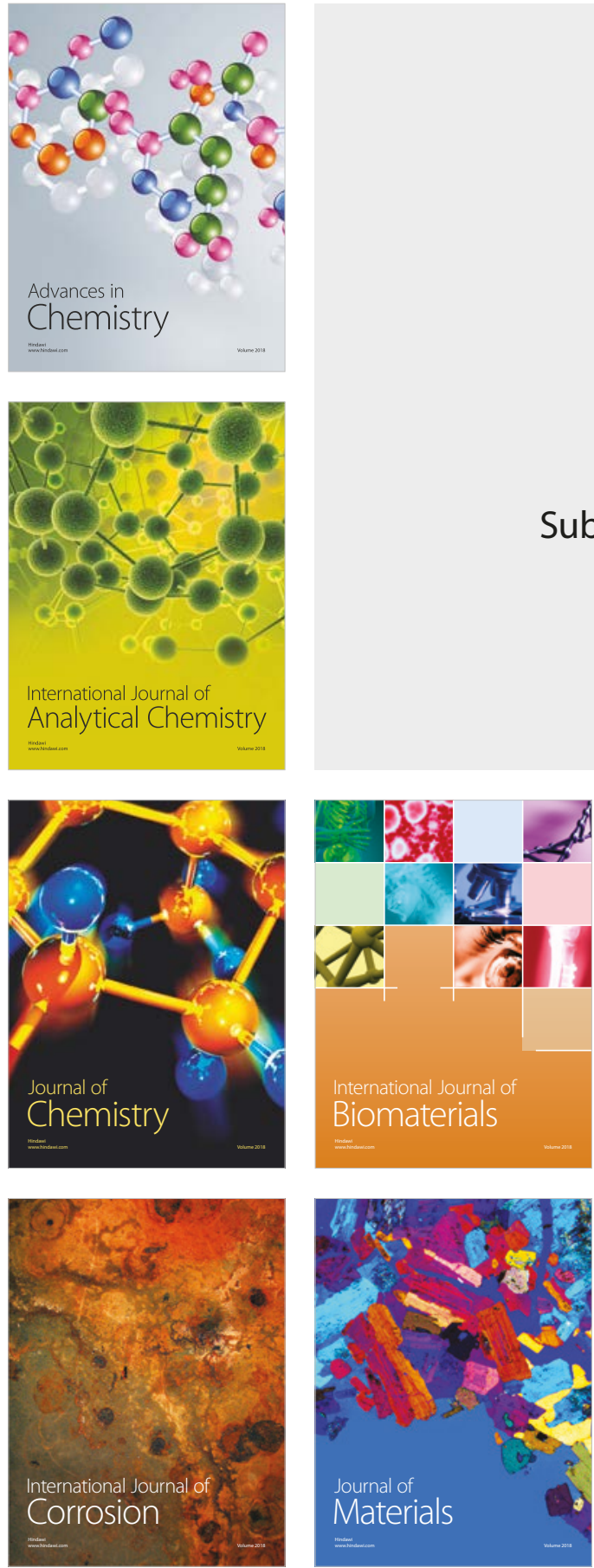

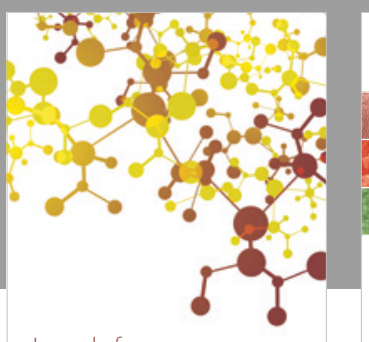

Journal of

Applied Chemistry
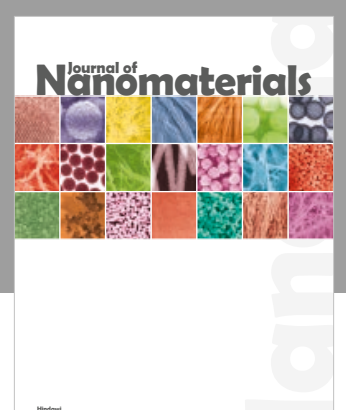

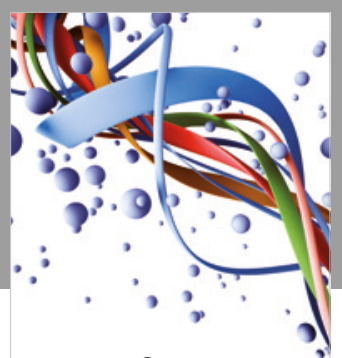

Scientifica

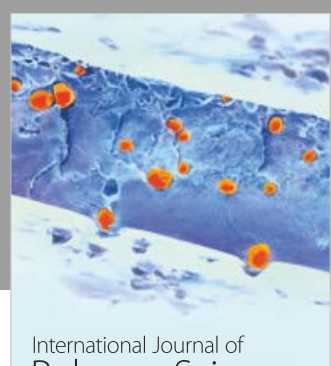

Polymer Science

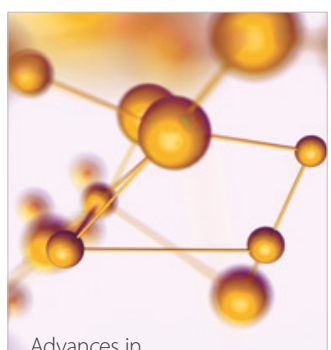

Physical Chemistry
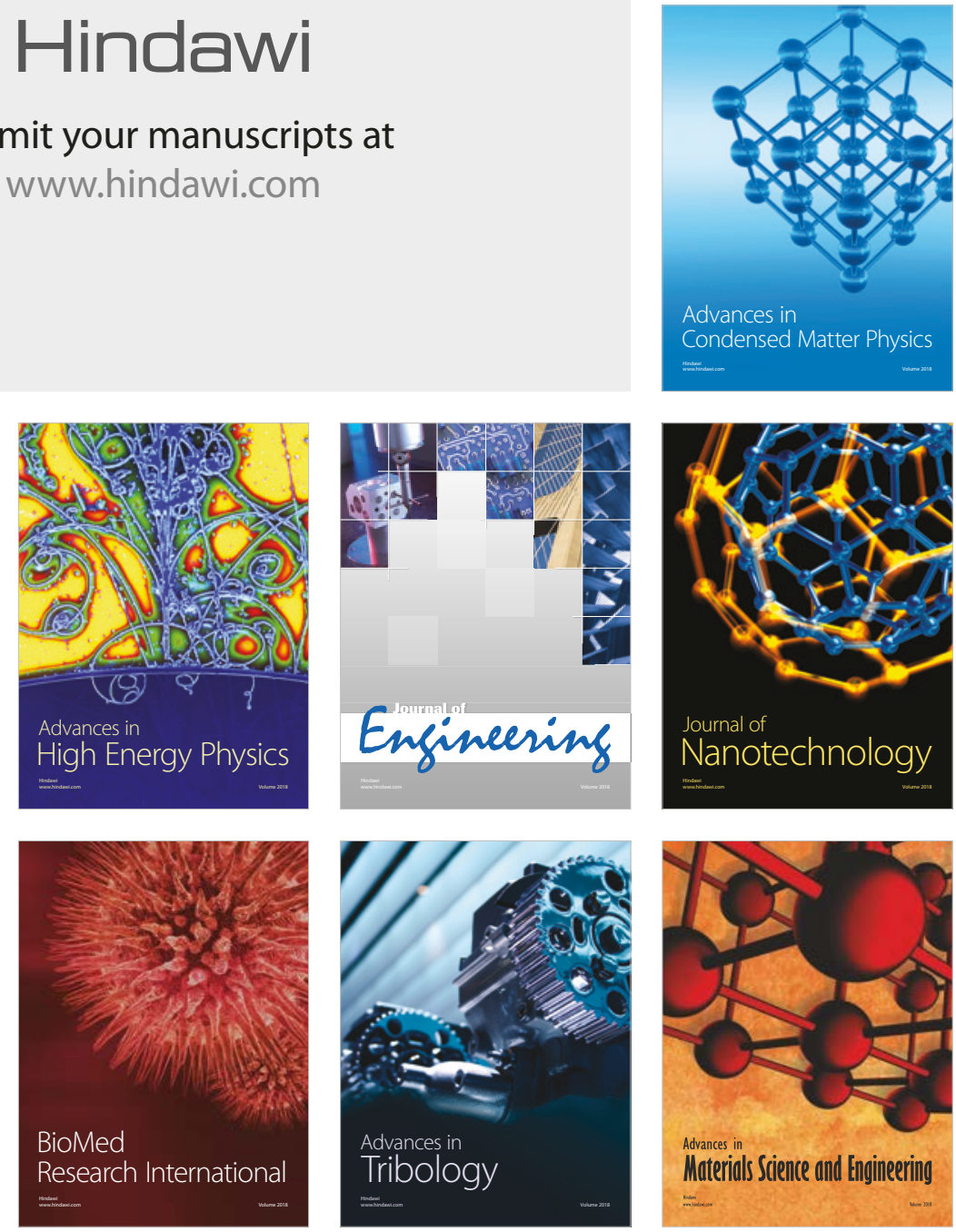